Open Access

\title{
Sue Farran and Jennifer Corrin* Developing Legislation to Formalise Customary Land Management: Deep Legal Pluralism or a Shallow Veneer?
}

DOI 10.1515/ldr-2016-0017

\begin{abstract}
One of the many post-colonial claims of indigenous people is the re-assertion of their rights over their land and its resources. Colonial history has created for many people a plural legal system and this, combined with social and economic changes, presents new challenges for development in the realm of traditional or customary land. This article focuses on the Pacific island state of Vanuatu, formerly known as the New Hebrides. At independence in 1980 allodial title to all land was returned to the custom owners while colonial forms of land law were also retained. In 2013, after nearly a decade of concern about land alienation, the Vanuatu government introduced the Custom Land Management Act. This article critically analyses this attempt to safeguard customary law and customary institutions in formal, written law, considering in particular the implications for law and development in a plural land law regime.
\end{abstract}

Keywords: indigenous, land rights, customary laws, legal pluralism, South Pacific

\section{Introduction}

The Declaration on the Rights of Indigenous People ${ }^{1}$ recognises the,

Need to respect and promote the inherent rights of indigenous peoples which derive from their political, economic and social structures and from their cultures, spiritual traditions, histories and philosophies, especially their rights to their lands, territories and resources (emphasis added).

1 Adopted by the General Assembly on 13 September 2007.

*Corresponding author: Jennifer Corrin, TC Beirne School of Law, St Lucia, Brisbane, Queensland 4072, Australia, E-mail: j.corrin@law.uq.edu.au

Sue Farran, Department of Law, Northumbria University, Newcastle upon Tyne, Tyne and Wear, United Kingdom of Great Britain and Northern Ireland

(c) BY-NC-ND ( 2017 Farran and Corrin, published by De Gruyter. This work is licensed under the Creative Commons Attribution-NonCommercial-NoDerivatives 3.0 License. 
Although, in the context of the Declaration, this largely refers to rights of indigenous peoples not to be forced off their land or denied traditional land rights, ${ }^{2}$ it might also be taken to include the right to manage their land according to patterns of indigenous or customary land tenure. ${ }^{3}$ At the same time the United Nations recognises the right to development as one of the most fundamental of human rights. ${ }^{4}$ While there is debate over what this means and whether it is valuable, ${ }^{5}$ this article focusses on one case example of how the alienation of land to meet development demands has triggered legislation which itself raises questions about post-colonial control over land policy and the practicalities involved in the search for legislative solutions in plural legal systems.

The country under consideration is the Republic of Vanuatu, which has the status of a Least Developed Country (LDC) and of a Small Island Developing State (SIDS). Prior to independence in 1980 the country, known then as the New Hebrides, came under Anglo-French Condominium colonial control. These metropolitan powers introduced their laws into the country, while at the same time tolerating the continued existence of customary laws provided these did not conflict with those of the settlers or colonial authorities. Land was a site of contestation, not only historically between indigenous people but between different groups of settlers and ultimately between indigenous people and foreign settlers. As Said stated:

The battle in imperialism is over land, of course; but when it came to who owned the land, who had the right to settle and work on it, who kept it going, who won it back, and who now plans its future - these issues were reflected, contested, and even for a time decided in narrative... The power to narrate, or to block other narratives from forming and emerging, is very important to culture and imperialism, and constitutes one of the main connections between them. ${ }^{6}$

In Vanuatu, the impetus for this new legislation can be traced back to the colonial legacy, especially the alienation of land to foreign settlers, and the introduction of laws and legal institutions which put in place non-customary forms of land tenure, which continue to be applicable today. The legal narratives of the indigenous and non-indigenous forms are very different, giving rise not

2 See in particular Articles 10 and 11.

3 See for example Articles 18, 20, 26 and 27.

4 See the UN Declaration on the Right to Development A/RES/41/128, 1986 and the Istanbul Declaration and Programme of Action for LDCs for the decade 2011-2020.

5 See for example, A. Vandenborgaerde, The Right to Development in International Human Rights law: A call for its Dissolution, 31 Netherlands Quarterly of Human Rights, no. 2 (2013), 187-209. 6 E. Said, Orientalism (New York: Pantheon, 1978), p. xiii. 
only to a plural legal system of land tenure, but also to tensions about the management of land informed by heterogeneous understandings and values. While Said's words might appear to be out of place in a post-colonial context, recent legislative developments in Vanuatu relating to the management of land held under customary tenure point to the continuing importance of who controls these narratives and how they do so. In attempting to rebalance control of the narrative this new legislation walks a tightrope between these pluralities potentially changing the dynamics of the laws that govern land, the nature of legal pluralism in the country's legal system, and the future for development in this SIDS.

This article locates this development within the context of debates about legal pluralism, hybridity, customary laws, and broader contemporary discourses about indigenous collective and individual rights. In particular, this case-study illustrates the challenges of developing legislation in resource-constrained contexts and the significant impact that certain agents can have on legal frameworks in small jurisdictions.

\section{A plural legal system}

Most Pacific island legal systems are plural, combining formal laws, introduced under colonial influences and retained in post-colonial times, with international and national laws, and with the customary legal system. However, the extent and depth of this pluralism, or even whether it amounts to pluralism at all, ${ }^{7}$ is a matter of contention. This is due not least to the inferior status accorded to unwritten, informal but nevertheless quotidianly applicable customary laws, both by the legislation and, in practice, by the courts. The Vanuatu innovation considered here, namely the Custom Land Management Act 2013, could be seen as reversing this trend. Alternatively, it could be viewed merely as an example of the hybridisation that occurs when government seeks to give effect to customary laws within the formal legal system.

7 J. Griffiths, What is Legal Pluralism? 24 Journal of Legal Pluralism (1986), 1-55, 8. For an alternative view see B. Dupret, Legal Pluralism, Plurality of Laws, and Legal Practices: Theories, Critiques, and Praxiological Re-specification, 1 European Journal of Legal Studies, no. 1 (2007), 296-318. 


\subsection{Deep pluralism/weak pluralism}

In discussions of the meaning and scope of legal pluralism a distinction is sometimes drawn between 'state' or 'weak' legal pluralism, and 'deep' or 'strong' legal pluralism. The refers to the coexistence of two or more bodies of norms or the coexistence of legal orders with different sources of authority. Griffiths has criticised state legal pluralism as a facade, serving only the interests of the State. ${ }^{8}$ However, other scholars, such as Woodman, whilst acknowledging the distinction, disagrees with the assertion that 'state' legal pluralism does not qualify as legal pluralism. ${ }^{9}$ State law pluralism may be seen as weak however, because the state retains its dominant position through the instrumentality of judicial review, the superiority of a bill of rights or other overarching fundamental principles, and its power to pass legislation to exclude or restrain the operation of customary law. ${ }^{10}$ Deep legal pluralism would therefore be evidenced by absence of state control, parity with or superiority over a bill of rights, and entrenchment, probably through a constitution, which would make it difficult for legislation to encroach on its domain. Not all plural systems fall within this binary and these various elements may be positioned anywhere across a broad spectrum of positions.

In the Pacific, this jostling for position usually involves customary laws and the status to be attributed to them in the formal system. Prior to the passing of the Custom Land Management Act 2013, which is the focus of this article, Vanuatu has had a rather schizophrenic approach to legal pluralism: hovering between State/weak legal pluralism and deep legal pluralism. The new legislation gives the initial impression of embracing deep legal pluralism, but a closer examination suggests that the reality may not live up to this perception.

The dilemma of what to do about legal pluralism in Vanuatu arises largely as a consequence of the country's history. At independence the new state retained a legacy of French and British law, along with joint regulations

8 See Griffiths (1986), supra note 7.

9 G. Woodman, “The Idea of Legal Pluralism”, in B. Dupret, M. Berger and L. Al-Zwaini (eds.), Legal Pluralism in the Arab World (Leiden: Brill, 1999), pp.3-19; Bradford Morse and Gordon Woodman (eds.), Indigenous Law and the State (Dordrecht: Foris Publications, 1988).

10 See Griffiths (1986), supra note 7; F. Von Benda Beckman, Citizens, Strangers and Indigenous Peoples: Conceptual Politics and Legal Pluralism, 9 Law and Anthropology (1997), 1-42. 
passed by the condominium government, ${ }^{11}$ and a body of case law from both Metropolitan systems. ${ }^{12}$ In practice, the civil law has played a very limited role since $1980 .^{13}$ Also in place and enduring the period of colonial rule were custom and customary laws, unwritten and diverse. ${ }^{14}$ The 1980 Constitution retained all these laws in force. ${ }^{15}$ There is therefore both formal and informal law and, in fact, customary laws are found in both, as reference is made to the role of custom and customary laws in the Constitution. ${ }^{16}$

In spite of this constitutional recognition and regardless of the rapid social and economic changes that have taken place since independence, there have been few, if any, development initiatives designed to bridge the practical divide between the customary and State systems. This could be done either by legislation (an example of which is the focus of this article) or by judicial activism, for example by using the constitutionally enshrined bill of rights. In Vanuatu, however, the avenue for judges to use human rights as a platform for advancing non-state law is narrow, as there is no direct protection of cultural rights. Although the courts could utilise the right to protection from discrimination of, inter alia, 'religious or traditional beliefs', ${ }^{17}$ in fact, where customary land

11 Constitution, art 95(1). Joint Regulations include Resolutions passed by the elected Representative Assembly after 1977, which, when approved by the Resident Commissioners, were enacted as Joint Regulations.

12 See further, J. Corrin, Bedrock and Steel Blues: A Study of Legal Pluralism in Vanuatu, 24 Commonwealth Law Bulletin, no. 1 and 2 (1998), 594-612.

13 See further, J. Corrin, "Keeping It Civil: The Application of French and English Laws in Vanuatu”, conference paper, Australasian Law Teachers Conference, Canberra (2013) unpublished; S. Farran "A Microcosm of Comparative Law: The Overlay of Customary French and English Family Law in Present Day Vanuatu” (2004) Oxford U Comparative L Forum 4 at oucif. iuscomp.org. The three official languages are Bislama, English and French: Constitution, art 3(1). One of the interesting departures in the new legislation is that the new forms attached to the Land Reform (Amendment) Act 2013 are in Bislama, rather than either of the two other official languages.

14 Constitution, art 95(3).

15 Constitution of Vanuatu 1980 (the 'Constitution') art 95.

16 'Traditional Melanesian values' are referred to in the Preamble; there is provision for the establishment of a National Council of Chiefs composed of 'custom chiefs' (Chapter 5) with competence to 'discuss all matters relating to custom and tradition', and under Chapter 12 which deals with Land it is stated that 'All land... belongs to the indigenous custom owners' (art 73), 'the rules of custom shall form the basis of ownership and the use of land' (art 74),'The government shall arrange for the appropriate customary institutions or procedures to resolve disputes concerning the ownership of custom land (art 78(2)); and under the provisions relating to existing law custom is to be taken into account 'wherever possible' (art 95(2)) and 'customary law shall continue to have effect as part of the law of the Republic of Vanuatu' (art 95(3)). 17 Constitution of Vanuatu 1980 art 5(1). 
issues have been approached from a rights' based perspective the outcome has not always been to favour the non-state law. ${ }^{18}$

In any event, distinguishing these forms of pluralism through the binary of state/non-state law may be unhelpful where, for example, the role of formal government is weak, or the agents and institutions which at first sight appear to be local and indigenous are in fact State creations. ${ }^{19}$ However, a consideration of the depth of legal pluralism in the sense of whether State recognition extends only to incorporation of customary laws within its own body of norms (weak pluralism) or goes further to acknowledge the law-making powers of customary institutions (deep legal pluralism) is a useful exercise in assessing the level of State commitment to customary laws and institutions as part of its development strategy.

Another lens for the analysis of the customary land management developments in Vanuatu can be found in Ori Aronson's suggestion that there are two forms of pluralism that might accommodate divergence and choice: mimetic pluralism, which imitates and accommodates existing pluralities; and poietic pluralism which creates new alternatives for engagement. ${ }^{20}$ The first is a passive response which acknowledges multiculturalism, affords dignity and respect to difference; the second is proactive or creative pluralism and involves the state in designing institutions which allow and facilitate multiple alternatives, thereby manifesting engagement with the questions of choice. Both might be said to be top-down, and both might result in the exclusion or marginalisation of some choices, ${ }^{21}$ the restriction or expansion of autonomy of actors within the plural system and be context contingent in so far as the range and relevance of choices might change over time or in particular circumstances. ${ }^{22}$

18 See e. g., Noel $v$ Toto (Unreported. Supreme Court, Santo, Vanuatu, Kent J, 19 April 1995) available via www.paclii.org at [1995] VUSC 3.

19 For example, the National Council of Chiefs which was established under the Constitution and is composed of custom chiefs 'elected by their peers': Constitution of Vanuatu 1980 art 29. It appears to have first emerged as a basis for the elections in 1976 shortly before independence private correspondence 9/04/2016. See also the Customary Land Tribunals established under the Customary Land Tribunal Act Cap 271, now repealed by the Customary Land Tribunal (Repeal) Act 2013.

20 O. Aronson, “The How Many Question: an Institutionalist's Guide to Pluralism”, in L. Batnitzky and H. Dagan (eds.), Institutionalizing Rights and Religion (Cambridge: Cambridge University Press, 2017) (forthcoming).

21 See, for example, the use of state-down legal pluralism to determine what practices/persons/ forums are included/excluded: Y. Sezgin, Legal Unification and Nation Building in the Post-Colonial World: A comparison of Israel and India, 8 The Journal of Comparative Asian Development (2009), 273.

22 For example, we see this in customary land, where ways of acquiring land historically, such as by conquest, may no longer be practiced today. 
These considerations are useful when looking at the accommodation or proactive facilitation of pluralism in the context of development in the form of legislative reform, and are illustrated by the Custom Land Management Act. Initially it appears that the legislation adopts a mimetic approach accommodating diversity through its non-prescriptive adoption of terms such as 'custom', 'family', 'nakamal' and 'head of a nakamal', 23 and recognition of different focal points for customary land management. Closer scrutiny, however, reveals there may be a failure to accommodate the range of existing pluralities in a country where custom is not homogenous, a point that will be returned to later, and there may in fact be a failure to tolerate multi-cultural perspectives. For example, one purported aim of the legislation is to make it more difficult to lease land, ${ }^{24}$ due to the concern of the rapid alienation of land, often to non-indigenous investors though leases and sub-leases. ${ }^{25}$ For custom land owners who want to do so, however, their autonomy to choose is being hampered by the Act. Similarly, recourse to traditional forums of dispute resolution may sit uneasily with the dynamics of change, especially urbanisation, waged employment, challenges to the traditional status of chiefs and so on. Mimetic pluralism may in practice reflect only one reality. If social rules are set in a formal framework eventually they may no longer reflect the reality of contemporary society. This may be particularly problematic where customary rules are reduced to written form. ${ }^{26}$ In Australia, for example, the Australian Law Reform Commission advised against the codification of customary laws on the grounds that 'There would be a danger of imposing

23 The 'nakamal' is a key institution in the Act and is defined as 'a customary institution that operates as the seat of governance for a particular area. Members of a nakamal include all men, women and children who come under the governance jurisdiction of that nakamal. A nakamal may be related to a single custom owner group or extended family group, or may be related to a number of custom owner groups or extended family groups living in a village or larger area. The vernacular language terms for the customary institutions termed 'nakamal' in this Act are different in different localities across Vanuatu and include Farea in parts of Efate, Gamal in parts of Malekula, Naumel in Motalava and Jaranmoli in parts of Santo'.

24 S. McDonnell, Better protection for custom owners: key changes in Vanuatu's new land legislation, Outrigger: Blog of the Pacific Institute (4 March 2014), available at: <http://pacificin stitute.anu.edu.au/outrigger/2014/03/04/better-protection-for-custom-owners-key-changes-invanuatus-new-land-legislation/>, accessed 20 April 2016.

25 See, S. Farran "Selling the Land: Should it Stop. A Case-Study from the South Pacific", in M. Dixon (ed.), Modern Studies in Property Law (Vol. 5, Oxford: Hart Publications, 2009), pp. 289-311. 26 See further, T. Elias, “The Problem of Reducing Customary Laws to Writing”, in A.D. Renteln and A. Dundes (eds.), Folk Law (Wisconsin: Wisconsin Press, 1995), p. 319; T.W. Bennett and T. Vermeulen Codification of Customary Law, 24 African Law Journal, no. 2 (1980), pp. 206-219; M. Chanock, Law, Custom and Social Order: The Colonial Experience in Malawi and Zambia (Cambridge: Cambridge University Press, 1985). 
uniformity where none exists and of freezing aboriginal practice at an arbitrary date'. ${ }^{27}$ Any rigidity of customary laws may inhibit its ability to survive by accommodation - a consideration which is pertinent in a country such as Vanuatu, where land can only be mortgaged if under a lease, and where the use and management of land may be key to development as well as crucial to sustainability. ${ }^{28}$

Alternatively, it might be argued that this legislation is evidence that the state is acting pro-actively (poietically) by institutionalising pluralism in the formal law. As we discuss below, however, the type of pluralism accommodated in the legislation may be more a plural hierarchy than a deep plural approach to customary land management, and may result not in poietic pluralism but in a form of paternalism. This prompts another way of examining a plural structure, which is to consider how the various laws, agencies and institutions function in practice rather than in theory, and whether that functioning indicates a deep or state pluralism. Here it might be asked, and this reflects the quote from Said, who exercises the power, what is the extent of the jurisdiction and what controls or sanctions are used to rein in that power? As will be seen, in the case of Vanuatu, it appears that control vests in a combination of state centred bureaucracy and a patriarchal minority.

\subsection{Legal hybridity}

A further factor to consider is that developments that may initially appear to be fostering legal pluralism may actually form a conduit to hybridity, so that the distinctive characteristics of a formerly plural system, whether identified as weak legal pluralism or deep legal pluralism, are blurred through a process of merger or blending. The concept of legal hybridity emerges most often in discussion about mixed legal systems, a term which is most commonly used to refer to the situation where different types of law are 'mixed' together within the same system. In the context of Vanuatu this occurs both within the State system, where the common law and civil law are still in force, ${ }^{29}$ and in the customary system, where customary laws differ from place to place. This lack of homogeneity in the customary system is of great relevance, as the diversity of

27 A. Gupta (ed.), Human Rights of Indigenous Peoples (Delhi: Isha Books, 2005), p. 128.

28 See further, E. Coulson, "The Impact of the Colonial Period on the Definition of Land Rights”, in V. Turner (ed.) Colonialism in Africa (Cambridge: Cambridge University Press, 1971), pp. 192-215.

29 See Article 95 Constitution 1980. 
customary land laws in these islands is something that impacts upon any State development initiatives to accommodate these laws. Mixed and plural systems often overlap, as is the case in Vanuatu, and in both situations certain legal forms or institutions may emerge as hybrids. In some respects hybrids might be considered to be successful 'legal transplants' that have adapted or been moulded to the local environment, ${ }^{30}$ or which have emerged in an organic way, linking or adding another layer or dimension to an existing situation of plurality (an example might be courts or tribunals established to consider land disputes which include adjudicators drawn from traditional social organisations $^{31}$ and/or a mixture of formal and informal procedural and evidential rules). ${ }^{32}$ Successful hybrids provide tools for transition between the past and the future, and are key to rooting development in the local context.

\section{Law and land in Vanuatu}

It is in their approach to land management, that South Pacific countries have been particularly divided between weak pluralism and deep pluralism, largely as consequence of colonial and post-colonial influences, the latter including the pressures of development and shifts towards greater individualism. In Vanuatu, for example, and strongly influenced by the politics of independence and a history of land alienation to foreign settlers, the Constitution demonstrates deep legal pluralism by providing that 'ownership' and use of customary land is to be governed by customary laws. ${ }^{33}$ Customary institutions are not, however, given exclusive power: State land laws govern leases and strata-title but, pursuant to the constitutional mandate, these laws co-exist with customary laws governing allodial title. The retention of introduced land laws which permit the leasing of customary land also means that there may be multiple forms and forums affecting land. Norms emanating from both systems can apply to the same parcel of land, and, whilst governing different types of property interests, they intersect at various points. Until recently, however, in the context of land, Vanuatu has not been prepared to go beyond State legal pluralism. Whilst it has established courts, ${ }^{34}$ and more recently tribunals, which have been

30 An example from neighbouring Solomon Islands is the introduction of the perpetual estate to take the place of freehold land: Land and Titles Act Cap 133, s 112.

31 See, e. g., Local Courts Act Cap 19, s 3.

32 See, e. g., Island Courts (Criminal Procedure) Rules 2005, Rule 5.

33 Constitution of Vanuatu 1980, art 74.

34 Constitution of Vanuatu 1980, art 52. 
designated as 'customary', by state legislation, ${ }^{35}$ it has failed to acknowledge the capacity of customary forums to adjudicate land disputes, although by omission it has allowed them to do so. So why the change?

\subsection{Development and the impetus for land law reform in Vanuatu}

In the early years after independence land leasing activity was modest, being confined primarily to agricultural leases of thirty or forty years. ${ }^{36}$ However as the economy developed and diversified there was an increase in leasing activity for non-agricultural leases, of longer duration (up to seventy-five years) and escalating activity in the development of sub-division and related sub-leases. ${ }^{37}$

Resolution of customary land disputes had been an ongoing problem preand post-independence. Original dispute resolution jurisdiction in the postindependence period lay with the island courts. ${ }^{38}$ However, so many cases were being appealed that in 2000 the Supreme Court refused to hear any more appeals. In 2001, the jurisdiction of the island courts over customary land was transferred to customary land tribunals. Intended to draw on the knowledge and processes of custom landowners and dispute forums, the Customary Land Tribunal Act, which forms a good example of legal hybridity discussed above, ${ }^{39}$ established a complex multi-layered system for adjudicating customary land disputes. This system was developed to work in parallel to the formal court system which retained jurisdiction for leases, despite the obvious potentially overlapping areas of litigation. Cross-over was limited to judicial review by the Supreme Court in cases where there had been failure of due process. ${ }^{40}$ In practice, cases continued to be heard by Island Courts, and a fair number

35 Island Courts Act Cap 167; Customary Land Tribunal Act Cap 271 (Vanuatu).

36 See S. Farran, Land Leases: Research Ministerial Leases in Efate, Vanuatu, 6 Journal of South Pacific Law, no. 2 (2002). available at: <<http://www.paclii.org/journals/fjSPL/vol06/6.shtml>, accessed 19 October 2016. and S. Farran, Report on Land leases and the Use and Management of Land in the Island of Efate, Vanuatu (2002) Research Report for the Minister of Lands, Vanuatu. 37 See ibid and more recent data 'Leases in Vanuatu' Key data from the World Bank Jastis Blong Evriwan Vanuatu National Leasing Profile', available at: <http://siteresources.worldbank.org/ INTJUSFORPOOR/Resources/Vanuatu_Leasing_Data_Summary.pdf>, accessed 20 April 2016.

38 Island Courts Act Cap 167.

39 See further D. Evans, M. Goddard and D. Paterson 'The Hybrid Courts of Melanesia' Justice for the Poor, Justice and Development Working Paper Series No 13 (Washington: The World Bank, 2010).

40 Customary Land Tribunal Act 2001s 39. 
found their way to the Supreme Court. ${ }^{41}$ This attempt to introduce a hybrid institution which would strengthen the role and recognition of customary laws in respect of land tenure caused considerable dissatisfaction, resulting in an extensive review of the customary land tribunals in 2005 and again in $2009 .{ }^{42}$ In 2011, the report of the 2009 review was published, ${ }^{43}$ leading to the abolition of Customary Land Tribunals in 2013. ${ }^{44}$

\subsection{A changing landscape}

The Custom Land Management Act was promoted as giving effect to the provisions of the 1980 Constitution under which Parliament undertakes to 'provide for the implementation of Articles 73, 74 and 75 in a national land law' (Art 76), but came thirty-four years after independence. It seems to have been triggered by the coincidence of a number of factors. First there was the establishment of the Land and Justice Party in 2010 by Ralph Regenvanu. The political platform of Regenvanu's new party was to resist foreign ownership of land and businesses in Vanuatu and make greater use of customary dispute resolution forums. It was hardly surprising that when he was appointed Minister for Lands in 2012 his election commitment was to develop land law in line with the resolutions of the National Land Summit held in 2006, which had articulated a number of contemporary concerns about land management triggered by a growing awareness about the rate of land alienation. Extensive data research and field studies undertaken in 2010-2012 confirmed earlier findings concerning the rapid pace of land alienation through the granting of leases over customary land, and that this showed no signs of abating. ${ }^{45}$

41 See e. g., Manlaewia v Maripopongi [2015] VUSC 119; Uritalo v Chilia [2016] VUSC 9.

$42 \mathrm{~J}$. Simo, Report of the national review of the Customary Land Tribunal program in Vanuatu (Port Vila: Vanuatu National Cultural Council, 2005); J.Simo and H. Van Trease The Vanuatu Customary Land Tribunal system, J4P World Bank, available at: <http://siteresources. worldbank.org/INTJUSFORPOOR/Resources/VanuautcusotmaryLandTribunalSystem.pdf>, accessed 1 July 2016.

43 H. Van Trease and J.Simo, "Report on the Activities of the Vanuatu Customary Land Tribunal and the 2001 Act”, NZAID, February 2011.

44 Customary Land Tribunal (Repeal) Act 2013.

45 "Leases in Vanuatu: Key Data from World Bank Jastis Blong Evriwan, Vanuatu National Leasing profile”, available at: <http://siteresources.worldbank.org/INTJUSFORPOOR/Resources/ Vanuatu_Leasing_Data_Summary.pdf $>$, accessed 20 April 2016. 
Secondly, around the same time the advocacy of an Australian lawyer on behalf of custom owners who were attempting to get a dubious lease revoked drew the attention of the media. The Minister for Lands subsequently engaged her as a consultant to assist in the drawing up of the Act.

Thirdly, an Australian funded initiative entitled 'Mama Graon', 46 had raised a number of concerns in the press and public. This project was a phase in a longer term initiative by the Australian development assistance Pacific Land Programme, which had been operating in Vanuatu prior to the 2006 Land Summit and had contributed to the shaping of the national Land Framework in 2011. ${ }^{47}$ The national Land Framework and the Mama Graon initiative, which included the objectives of mapping customary owners and customary boundaries, were part of the response to concerns about land alienation, but also integral to an aid-funded project entitled 'Making Land Work' aimed at development. ${ }^{48}$ Negative publicity and rumours led to the suspicion by some that this exercise was a covert way of facilitating the sale of land to foreigners. ${ }^{49}$ As a result, aid funded intervention in land turned its attention away from customary land to the administration of leases, registration of title and the improvement of land department systems. ${ }^{50}$

Finally, media exposure and cases coming before the courts revealed continuing abuses of power by various Ministers for Lands, leases being registered where custom ownership and therefore the power to grant the lease were contested, and disputes over the calculation and distribution of financial benefits arising from leases, in particular the assessment of premiums payable. In other words, the only developments since the 2006 Land Summit were for the worse and the public was increasingly aware of this sorry state of affairs.

46 This 'label' was intended to indigenize an aid funded land reform programme by capitalising on the Melanesian notion of 'land as mother'.

47 There had for example been a comprehensive review of land legislation published by C. Lunnay, J. Fingleton, M. Mangawai, E. Nalyal and J. Simo, Review of National Land Legislation, Policy and Land Administration (Port Vila: Vanuatu Government, 2007), which included a section on the reforms necessary to give effect to the National Summit resolutions. 48 Publication in two volumes was part of AusAID's Pacific Land Programme: 'Volume One Reconciling Customary Land and Development in the Pacific'; Volume Two - Case Studies of Customary Land and Development in the Pacific' Australian Government Department of Foreign Affairs and Trade 2008 Canberra.

49 See open letter addressed to the Prime Minister "National sovereignty under threat" Jeff Joel Patunvanu, The Independent, 7 July 2012.

50 On funding issues see J. Joshua, "Mama Graon Program a Package of Funds: Nari”, Vanuatu Daily Post, June 28 2012, 3. It is estimated that this Australian aid package focussed on land has reached over 2.4 million AUD (interview Port Vila August 13, 2015). 


\section{The new legislation}

\subsection{Development}

The law reform exercise was primarily undertaken by a small committee led by the Minister for Lands which included the Australian consultant referred to above. There was also an advisory committee which met four or five times in 2013 to consider proposed drafts. ${ }^{51}$ The law was gazetted early in $2014 .^{52}$ In the months that followed forms and regulations were drafted, amendments to the legislation put in place, funding sought for the administration and supporting structures of the new law and, towards the end of the year, a Land Management Planning Committee chaired by Professor Don Paterson, a long-time resident of Vanuatu and law academic at the University of the South Pacific, was appointed..$^{53}$ The role of the Committee was to consider all applications for the issuance of a negotiator's certificate, the first step in the new lease application process. $^{54}$ The committee met for the first time in October 2014 and then regularly on a monthly basis since then considering applications and forwarding these where approved to the National Co-ordinator of the Customary Land Management Office. ${ }^{55}$ In 2015 one hundred and thirteen applications were forwarded. ${ }^{56}$ The next stage consists of the issue of a green notice to the applicants to advise that the application is proceeding, and physically posting of notices on the land to alert custom owners and others of the proposed lease negotiations. ${ }^{57}$

The passing of the new Act was accompanied by other legislative changes to the Land Leases Act, ${ }^{58}$ and the Land Reform Act. ${ }^{59}$ While amendments to the

51 Drafts were also sent to one of the authors of this paper in the last quarter of 2013 for comment.

52 The Act commenced on 20 February 2014.

53 Membership is set out under s8A of the Land Reform (Amendment) Act 2013 and the powers and remit of the committee and set out in the revised section 8. Professor Paterson was appointed early in 2014; the other members were appointed later under the statute.

54 See revised sections 6-7, Land Reform Act Cap 123.

55 In April 2016 it presented its first report to the Minster for Lands. At the time of writing this has not yet been tabled before parliament and so is not in the public domain.

56 Personal communication 27 March 2016.

57 It is unclear whether any such notices have yet been posted. Personal communication 27 March 2016 indicated very few if any.

58 Land Leases (Amendment) Act 2013, which came into effect on 27 February 2014. See also Land Leases (Amendment) Act 2014, which came into effect on 27 February 2015.

59 Land Reform (Amendment) Act 2013, which came into effect on 20 February 2014. See also Land Reform (Amendment) Act 2014, which came into effect on 24 June 2014. 
former were minor terminological amendments, those to the latter were more extensive and were aimed at preventing the Minister for Lands from approving land dealings unless they had been through the Land Management Planning Committee process and the consent of custom owners had been given. ${ }^{60}$ The Land Reform (Amendment) Act also provided for the appointment of a Land Ombudsman whose potential usefulness was undermined by the very limited powers of oversight conferred by the legislation.

Two amendments to the Constitution were also made: ${ }^{61}$ the first made it compulsory for Parliament to consult with the Malvatumauri (National Council of Chiefs) before making any changes to land law, ${ }^{62}$ the second, put customary land dispute resolution in the hands of customary institutions and provided that, after being recorded in writing, their decisions were binding and not subject to appeal or review by any Court. ${ }^{63}$ The responsible Minister was quoted as stating that the 'new laws bring determination of custom owners back to customary institutions; it removes the power from courts and the government to determine who the custom owners are and puts it back under rules of custom. ${ }^{64}$ There is therefore limited recourse to the formal court system, and this may be evidence of a deep legal pluralism. However, whether the power is removed entirely from government and whether all the institutions established by the legislation are truly customary will be considered below.

\subsection{Implementation and operation}

Political expediency and the timing of parliamentary sittings meant that there had been little time to consider the practical implementation of the new legislation at the drafting stage. Once gazetted, in February 2014, these implications had to be worked out.

Interviewed on Radio New Zealand International in February 2015, the Minister for Lands, pointed out that one of the immediate positive effects had been to put a brake on the creation of new land leases, however, he also acknowledged that 'whether this new process of identifying customary ownership is going to work is still a question. We are starting to pilot it now.

60 The Act also further defines the role provided for the Council of Chiefs under Article 30 of the Constitution.

61 Constitution (Sixth) (Amendment) Act 2013, Schedule.

62 Constitution, art 30(2), as amended by Constitution (Sixth) (Amendment) Act 2013, Schedule.

63 Constitution, art 78, as amended by Constitution (Sixth) (Amendment) Act 2013, Schedule.

64 S. McDonnell, New Territory, Pasifika, ANU, available at: <http://pasifika.anu.edu.au/newsevents/all-stories/new-territory>, accessed 29 June 2015. 
It's more expensive than the old process. There are a lot more steps to be taken. There's still uncertainty about whether that is actually going to work' ${ }^{65}$

An initial step was the creation of a Strategic Implementation Committee to look at the practical implementation of the Act, to consider various terms of reference and the working parameters of the new legislation. After that, the content and purpose of the new legislation was explained to the major land institutions in the capital, the Ministries of Justice and of Lands and the Lands Department in a familiarisation and awareness workshop in April 2014. Customary land officers in each provincial office, who had been being trained under the now repealed Customary Land Tribunal Act, ${ }^{66}$ were transferred across to be officers under the new Act. Once new training material had been prepared they were to be made aware of the new provisions and their new roles.

In early 2015 it was announced that the Act would be rolled out in stages, commencing with ten pilot projects which would involve community outreach and awareness programmes and intensive one week of training for chiefs, adjudicators and secretaries in the pilot areas from mid-February 2015. By the time of cyclone Pam in March 2015 some of the pilot areas had received the full package of awareness and training but further training was suspended due to the cyclone. ${ }^{67}$

In June 2015, there was a change of government and the new Minister for Lands stated initially that he would repeal the new laws. In August 2015, he announced a review, and published two terms of reference to review the legislation and land policy. ${ }^{68} \mathrm{~A}$ committee was formed and an internal, indigenous Land Policy Review Consultant appointed with a mandate to 'undertake a policy and legislative review of identified land legislation, make recommendations or changes that are required to existing legislation and propose approaches to future legislative drafting activities'. ${ }^{69}$ The proposed review was to last six

65 Radio New Zealand International 16 February 2015, available at: <http://www.radionz.co.nz/ international/programmes/datelinepacific/audio/20167398/vanuatu-customary-land-owner ship-process-begins>, accessed 20 April 2016.

66 Cap 271.

67 By the time of suspension just under half of the 2015 aid budget had been spent on the project. In total the land reform programme in Vanuatu has cost around \$AU 9 million from one aid source alone.

68 Personal communication 8 August 2016.

69 There were two Land Policy and Legislative Review statements brought to the author's attention during field work in August 2015, the first covered the Land Leases Act and Amendments, the Land Reform Act and Amendments, the Cus[to]mary Land Management Act and Amendments and the Strata Titles Act and Amendments. The second covers the Urban Land Act, the Freehold Titles Act, which exists on the books but has never been used, the Expansion of Urban and Provincial Areas and 'any land related policies and legislation including the 
months with the expectation that initial recommendations would be put before parliament at its October 2015 sitting. In the meantime, the Custom Land Management Act and the amended Land Reform Act and Land Leases Act remained in force. However, the progress of cases from the pilot areas ground to a halt. $^{70}$ The aid-funded programme running training and awareness pilot projects were put on hold due first to cyclone Pam and then to the antipathy of the new Minister for lands. Funding ceased entirely by the end of 2015. By that time, parliament had also been disbanded and the government was in disarray following the criminal convictions of several of its members, including the Minister for Lands ${ }^{71}$ As a consequence, the committee appointed to review the legislation seems to have simply faded away.

Elections to form a new government were held in January 2016 and saw Regenvanu reinstated as Minister for Lands. In its 100 Day Plan, the Vanuatu government included a review of land laws to facilitate economic development activity under its medium to long term plans to be undertaken by November 2016. ${ }^{72}$ The Land Management Planning Committee continued to meet throughout this politically stormy period, however, after over a year since the law was gazetted only three negotiator certificates had been granted and all of these to ni-Vanuatu wanting to negotiate leases over their own land. ${ }^{73}$ The government put the target of fifteen negotiator certificates in its 100 Day Plan. There is no reference to the remainder which have been forwarded by the Committee to the Customary Land Management Office for processing. As at mid-May 2016 it appeared that only five negotiator's certificates had been awarded and these had all been to applicants whose claims have been previously adjudicated by an Island Court, the Supreme Court or a Customary Land Tribunal. Indeed, it appears that no determinations of ownership have as yet been made by the

Physical Planning Act. Whether these were two separate calls for separate consultants or simply a revised call was not clear.

70 Research undertaken in August 2015 indicated that applications which had been approved by the committee were being held at the Custom Land Management Office by the National Co-ordinator of Custom Land Management and were not being processed, although there was some talk of these being routed back to the Lands Department.

71 For insight into these events see D. Paterson, Chronicle of the Months of Political and Constitutional Crisis in Vanuatu 2014-2015, 2 Journal of South Pacific Law (2015), available at: <https://www.usp.ac.fj/fileadmin/random_images/home_middle_banners/emalus/JSPL/2015/ Issue_2/CHRONICLE_OF_THE_MONTHS_OF_POLITICAL_AND_CONSTITUTIONAL_CRISIS_IN_ VANUAT1_rev_.docx>, accessed 26 March 2016.

72 Priorities for Implementation by Vanuatu Government March-December 2016, available at: <https://vanuatudaily.files.wordpress.com/2012/02/salwai-govt-100-day-plan.pdf>, accessed 26 March 2016.

73 Personal correspondence 10 April 2016. 
customary nakamals, in line with the scope and purpose of the Act. ${ }^{74}$ Moreover, a further level of state intervention has been introduced (outside the scope of the legislation) whereby an adjudicated application is referred to the State Law Office by the Custom Land Management Office. The State Law Office has then to confirm that the decision of the adjudicating body can be interpreted as conferring ownership on the applicant seeking a negotiator's certificate. It must also be remembered that the grant of a negotiator's certificate is just the first stage in the process of securing a lease over customary land. In short the lived experience of the law raises questions about its workability.

\section{What does the custom land management act achieve?}

\subsection{Commitment to legal pluralism?}

As indicated above, Vanuatu's Parliament has a constitutional mandate, 'after consultation with the Malvatumauri Council of Chiefs' to 'provide for the implementation of Articles 73, 74 and 75 in a national land law and... make different provision for different categories of land'. Article 74 imposes an obligation to ensure that the 'rules of custom... form the basis of ownership and use of land in the Republic of Vanuatu.' One of the arguments in support of the Act is that it gives effect to these provisions, and it has been argued that 'the laws... represent a significant commitment to legal pluralism'. ${ }^{75}$ McDonnell, the drafter of the legislation, states that the legislation provides, ${ }^{76}$

a pragmatic response to the lived reality of contemporary legal pluralism and it is anticipated that this will provide for more accessible determinations of land issues at a local village or custom area level.

The question then arises whether the legislative and constitutional changes live up to this claim and acknowledge the legal powers of institutions

74 Personal communication 21 May 2016.

75 S. McDonnell, "Vanuatu Embraces Landmark Reforms", EASTASIAFORUM, available at: <http:// www.eastasiaforum.org/2015/03/14/vanuatu-embraces-landmark-reforms/>, accessed 20 April 2016. 76 see McDonnell, supra note 64 . 
constituted by customary law norms, in which case this would be an exercise in deep legal pluralism. ${ }^{77}$ Closer analysis of the new law casts doubt on the level of pluralism achieved by the Act, which does not in fact establish a "national land law'; rather it is an Act about processes and agencies, not about which rules of custom govern customary land. To that extent therefore heterogeneity is preserved, but at a mimetic level.

Whilst avoiding engagement with the substance of custom avoids the danger of converting it to state law, it could also be said to imply a misleading homogeneity in a country where - as has been stated, there is heterogeneity of customs relating to land. For example, one of the key features of the legislation is that disputes are to be decided by the nakamal. Although the Act recognises different indigenous words to describe these fora, the basic principle assumes a universality as to the status and influence of the nakamal, yet, as suggested below, research reveals widely differing views of the role and importance of the nakamal.

Further the title of the Act refers to the 'management' of land, but in fact its primary focus is on ownership and on increased formalities for customary owners, who must obtain a record of interest and/or apply for a negotiator's certificate before they can grant a lease over their land, even where their rights have been confirmed by a recognised legal forum. Currently about $80 \%$ of pending applications which have come before the Committee are those of indigenous people seeking to secure their land through a lease granted to themselves or members of their family. ${ }^{78}$ These applicants have to go through the same complex and time-consuming processes as a largescale foreign investor. What the Act has failed to provide for is a plurality of possibilities in the context of land development with the consequences that while there may now be safeguards in place to prevent custom owners from entering adverse leases without due caution, ordinary ni-Vanuatu are being frustrated from utilising their own land for their own benefit, in breach of their constitutional rights. This we would argue, is not deep pluralism but new hybridity.

77 See, e.g., B. Morse and G. Woodman, "Introductory Essay: The State's Options”, see Vandenborgaerde (2013), supra note 5, 17.

78 Personal correspondence 10 April 2016. Similarly, the Land Ombudsmen has files for ten cases where custom owners have been identified by the formal courts/tribunals and are seeking to get a record of their interests reflecting the judgment made in their favour. Interview Port Vila, August 10, 2015. 


\subsection{A new hybrid?}

The Custom Land Management Act opens with the following provisions:

(1) The Parliament of Vanuatu has formalised the recognition of customary institutions termed 'nakamals' and 'custom area land tribunals' in this Act to determine the rules of custom which form the basis of ownership and use of land in Vanuatu.

(2) The final decisions reached by these customary institutions, when appropriately recorded, become recorded interests in land which are binding in law and are not subject to appeal to, or judicial review by, any Court of law.

(3) The Act allows for mediation to progress the resolution of land disputes, and for an Island Court (Land) to review the decisions of a nakamal or custom area land tribunal on grounds of an incorrect composition, improper process or fraud. These areas of review are matters of process and not substance within the meaning of Article 78 of the Constitution.

At the outset it has to be pointed out that 'custom area land tribunals' are not creatures of custom. They are new bodies established under the legislation and although they may be informed in their composition and practice by customary practices this does not amount to deep legal pluralism. ${ }^{79}$ These tribunals are constituted by non-customary norms and, at best, can be described as hybrid institutions. Alternatively, they may be regarded simply as state institutions made palatable though the term 'custom', reflecting shallow or weak pluralism. Similarly the use of 'recorded interests' is not customary but transforms the traditional oral process of custom into the written recording system required by the State. The interaction of customary mediation, Island Courts and decisions of nakamals or custom land tribunals offers a hybrid spectrum of dispute mechanisms in which even the notion of customary mediation is a blended concept, subjected to a formal process involving formal nominations and written records, ${ }^{80}$ modelled on the State system. It is also interesting to note that in the three cases to date where a negotiator's certificate has been issued the aim of the applications has been to secure individual title to land, ${ }^{81}$ thereby using the process to move away from the traditional perception of customary land tenure as communal or collective towards the individualisation of occupation and use of custom land and the chance to develop this resource autonomously.

79 As explained by Morse and Woodman (1999), see supra note 9, p. 77.

80 Custom Land Management Act 2013 Part 5.

81 Personal correspondence 10 April 2016. 
Unlike the custom area land tribunal, the institution of the 'nakamal' is a customary one. Its role is explained in a note to the Act which states: 'this Act provides for the identification of custom owners and the resolution of land disputes by customary institutions in accordance with the rules of custom in a nakamal or custom area land tribunal. It also allows for voluntary mediation by disputing parties and strict rights of appeal of nakamal and custom area land tribunal decisions on grounds of process and fraud to a specially constituted Island Court (Land).' This provision suggests that the nakamal is the source of customary rules or procedures for doing two things: identifying owners of land held under customary land tenure and resolving disputes. The definition of nakamal given in the Act appears to be founded on an assumption that despite the different terms used the nakamal is accepted as a 'seat of governance'. ${ }^{82}$ However research into customary land tenure undertaken by law undergraduates at the University of the South Pacific over a number of years suggests that the role, function and respect afforded to nakamals is not the same throughout the country. ${ }^{83}$ For example, it is evident that as regards the first role of the nakamal envisaged by the Act - the identification of customary land owners, there are differences of practice. Student research found that in Wintua Village, South Malekula, it was explained that 'the nakamal gives a person their land rights. The nakamal is used when disputes arise including land disputes. When there is a land dispute each party must state which nakamal they belong to. According to our interviewee if a person has no nakamal he has no land. The nakamal signifies land ownership so when there is a land dispute each party must trace their ancestry to their land through their nakamal. ${ }^{84}$ Elsewhere the role of the nakamal (nasara) may be more indirect as explained in the case of Central Pentecost '(the) nasara is a place where chiefs attain their chiefly titles. Thus, a person claiming that he comes from a particular nasara would provide a wrong impression, because it would mean he is a chief. This would then make every person a chief, if they claim that they come from that nasara. Therefore, it is normally the practice that when determining ownership of land, people refer to their chiefly line. In other words, they refer to the line of the chief, which they

82 See ibid for definition.

83 This unpublished research was undertaken as part of their elective studies in Customary Land over a number of years from 2000 and although these students are by no means trained ethnographers their notes of interviews with local people provide some interesting insights into the plurality of customary land tenure in the country. See further, S. Farran, "Customs, Laws and Traditions: Bright Lines or Grey Areas?” in A. Albarian and O. Morétau (eds.), Le droit comparé et... Comparative Law and..., Actes de la conférence annuelle de Juris Diversitas (Presses Universitaires d'Aix-Marseille, 2016), pp. 65-74.

84 MML 2001 (unpublished). 
belong to. Therefore, through the chiefly line, people know which land belongs to them since it is the chief who allocates the land and also which nasara they belong to, since the chief owns the nasara. ${ }^{85}$

Similarly, in East Ambae Nasara is taken literally to mean the place where pig-killing ceremonies are held, which is essential for the ranking of chiefs. In East Ambae, it is also taken to mean a sacred place or the birthplace of someone. In the latter, this is taken to mean a place where a person grew up or spent his livelihood as a child to adulthood. ${ }^{86}$ In other words, the place where a person can identify him/herself as belonging to.

Elsewhere however there is evidence to suggest that the nakamal is merely a social gathering place and has no significance for land rights. In Aneityum, for example, the biggest nakamal, Entecjeb has been described as 'a big place surrounded by trees and stones, used for kava drinking, meetings and gatherings to resolve disputes' but that it has no significance with regard to land ownership probably because land is regarded as being owned individually. ${ }^{87}$ Similarly, in Hog Harbour in East Santo, the nakamal is regarded simply as a place for social gatherings, with no significance to the ownership of land. ${ }^{88}$ In Epi the meeting place for land owners in the Rovo Bay area was under a banyan tree rather than a nasara and it was this particular location which was believed to give strength to the clan to resist bad magic. ${ }^{89}$ Nevertheless claims of land entitlement were justified by tracing back to a nasara: 'The man whose blood comes directly from the nasara... which is situated within the boundary of the land, and who is directly related to the clan who originally own the area, is one of the true custom owners of that area of land'. ${ }^{90}$ These narratives suggest that the nasara or nakamal is a physical place, but may also or alternatively be understood as a social collective, for example the clan, ${ }^{91}$ associated with a bounded area of land.

In terms of the nakamal/nasara being the locus of dispute resolution, this is not always the consensual process which might be presumed. In many areas of the country the power to determine land rights or rule on disruptive behaviour lies with the chief, or the head of the family/clan or tribe. Moreover, near urban areas such as Ifira or Mele disputes tend to be taken to the formal courts.

85 FG 2001 (unpublished).

86 CA2001.

87 JA 2001.

88 LW/FW 2001.

89 JS2000.

90 JS2000.

91 NW Malekula. 
The central locality of the nakamal in the scheme of the Custom Land Management Act also fails to sufficiently take into account the different ways in which land might be acquired (other than by tracing claims back to those who first settled or discovered the land) or the movement of people, including intermarriage between people from different islands and the physical relocation of people due to missionisation, war or natural disaster. ${ }^{92}$ For example, student research found that land might be acquired as compensation or reward, by customary sale, or for other customary reasons, and the rights over that land could be diverse in scope and temporality.

These aspects of customary laws reflect the lived pluralism of land regardless of any state law, which challenges the uniformity of assumption which appears to lie behind the Act. This can be further explored by considering that the Act states that the meeting to determine custom owners 'must be convened in accordance with the custom of the relevant nakamal and all decisions of the nakamal must be made according to the rules of custom'. ${ }^{93}$ However, it then requires a quorum of at least two-thirds of the adult members of the nakamal to be present at the meeting in order to reach a valid decision, ${ }^{94}$ and in cases where membership exceeds 300, the decision must include at least one third of the adult members in order to be valid. ${ }^{95}$ Clearly these introduced quotas seek to ensure a democratic process, but they do not appear to be founded on custom, nor do they seem very practical given the mobility of the population. Although this has not yet been tested there may well be questions as to the legitimacy and legality of proxies or persons claiming to represent the interests of absent members of the nakamal.

The Act then goes on to prescribe that decisions 'must be made by consensus of the members of the nakamal in accordance with the custom of the custom area in which the nakamal is situated. ${ }^{96}$ As mentioned above, there is no evidence to suggest that consensus is the method of decision making throughout the country. Even where this might be the case, the stipulation in

92 See, for example, on Moso Island, where people have moved and inter-married with peoples from other islands; Ifira, Efate, which has a large population of incomers (man kam) and also historically returning blackbirders; South Ambae, where coconut plantations led to the movement of people.

93 Custom Land Management Act 2013 ss 15 and 17.

94 S 17(1).

$95 \mathrm{~S} \mathrm{17}(2)$. There is ambiguity in this part of the Act. The change of wording between s 17(1) and s 17 (2) suggests that mere presence is required in cases where membership is below 300 , but inclusion in the decision making process is required by the one third required to be present in other cases.

96 Custom Land Management Act 2013 ss 17(5), 25(5). 
the Act that members of the nakamal are defined to include women and children, ${ }^{97}$ who presumably are also to have 'an equal say' may be very different from local practices. Gender equality is not a strong feature of Vanuatu society. ${ }^{98}$ What is the situation if the rules of custom in the area in question do not allow for women and children to have a say in decisions relating to customary ownership (which will often be the case)? Does the legislation overrule custom here, reshape it or give way 'according to the rules of custom'? Indeed, the Act seems to be trying to given agency to women and children on the grounds of political correctness, and in compliance with the non-discrimination provisions of the Constitution, ${ }^{99}$ without addressing the gulf between normative idealism and reality.

In addition to the fact that the forums described as 'customary institutions' do not necessarily equate with customary practices in some areas of the country, there is the question of whether a development process which brings customary land tenure within a formal Act of Parliament may be regarded as converting it to State law. ${ }^{100}$ It is certainly not equivalent to living customary laws ${ }^{101}$ because it lacks customary law's flexibility to adapt, requiring amendment by Parliament or proactive interpretation by the courts for changes to take place. There are, moreover, provisions in the Act that may act as catalysts for change which do not evolve organically but as a consequence of state intervention. For example, written records are required to be entered into a central office and used as evidence of customary title. The, presumably, unintended result of this may be to provide a back door avenue to the registration of customary land title. The agents involved in the processes of the Act are also not solely customary. Besides the inclusion of traditional leaders there is also the hybrid institution of the Malvatumauri (the National Council of Chiefs) and State officials in government departments, such as lands and justice. This creates a complex hierarchy of central and local agents which bears little relationship to customary structures. Different forms of delineation are used for the various component parts of the administration of legislation, for example provinces, language, customs, islands, thereby offering a blend of traditional and state-constructed boundaries.

97 Custom Land Management Act 2013s 2(1).

98 See S. Farran, Gender, Equality and Pacific Island Countries with particular Focus on Domestic Violence, Journal of South Pacific Law (2015) (online).

99 Article 5(1).

100 See supra note 30.

101 G. Van Niekerk, "Legal Pluralism", in J. Christoffel Bekker, C. Rautenbach and N. Muhammed Ismail Goolam (eds.), Introduction to Legal Pluralism in South Africa (Durban: Lexis Nexis South Africa, 2002), p.1. 
It might be suggested, therefore, that rather than a deep engagement with pluralism this Act cleverly creates a new hybrid which straddles the ground between customary and state. This model is perhaps designed to appease concerns about the marginalisation of customary land management, but at the same time to vest control of leasing in the state through the various institutions and agencies established under the raft of new legislation. If we return to the quotation from Said, we might ask whose narrative dominates the law and what impact might this have?

\section{Conclusion}

The background to this legislation was very real concern about rapid and apparently uncontrolled alienation of land through the use of leases, sub-divisions and strata-title, all forms of land holding introduced either under colonial rule or post-colonially to contribute to development through 'making land work', either through the establishment of plantations and farms, or to support tourism and the market for second homes by foreign investors. Anxiety about the marginalisation of indigenous players and forums and a degree of paternalistic concern about indigenous custom owners of land being cheated or tricked out of their land culminated in this legislative innovation and reform. The Act is, therefore, an ambitious attempt to address the very real concerns raised under the National Land Summit in 2006 and which for too long have been ignored by government. Conceptually and in practice however, the Custom Land Management Act raises more questions than it answers. While there are a number of substantive concerns, particularly those relating to gender and finality of determinations which are beyond the scope of this article, but certainly need addressing, the focus here has been to consider how the legislation has dealt with and/or contributed to Vanuatu's plural legal system.

Quite clearly in the context of competing land management agendas, there is a challenge in preserving the positive aspects of custom land management and the forums that have survived to this day and operate outside but alongside the formal courts. This retention of tradition has to be balanced against challenges to tradition and changes in custom. In passing legislation to encompass custom land management there is the difficulty of embedding flexibility to adapt while providing certainty of present processes; of marrying the past with the present while making provision for the future.

The Act also illustrates the practical difficulties of drafting legislation in a western, formal arena, to address concerns which are experienced in diverse 
ways in the real lives of people observing heterogeneous customs. Too much detail makes the law proscriptive and restrictive, limiting choice in a customary system which itself is plural, and being perceived as overly paternalistic. It is also evident that too much complexity in process runs the risk of being unworkable or too expensive to be sustainable. Too little detail and there is the danger of conferring too much interpretative discretion on those who administer the law and, where there is insufficient accountability of those with this power, there is the risk that either the law will be ignored or that it will be abused. As we approach the end of 2016, with the Act not yet fully in force, it is too early yet to say with any certainty which of these two camps the Custom Land Management Act may fall into, but it has not had an auspicious start and it seems possible that it may be reviewed before it has really got going. If that is the case then it would seem that on this occasion not only has little has been achieved in advancing deep legal pluralism in this particular plural legal system, but also the attempt to accommodate different land development agendas has failed.

\section{References}

Aronson, 0., “The How Many Question: an Institutionalist's Guide to Pluralism”, in Loera Batnitzky and Hanoch Dagan (eds.), Institutionalizing Rights and Religion (Cambridge: Cambridge University Press, 2017) (forthcoming).

Bennett, T.W. and T. Vermeulen, Codification of Customary Law, 24 African Law Journal, no. 2 (1980).

Chanock, M., Law, Custom and Social Order: The Colonial Experience in Malawi and Zambia (Cambridge: Cambridge University Press, 1985).

Corrin, J., Bedrock and Steel Blues: A Study of Legal Pluralism in Vanuatu, 24 Commonwealth Law Bulletin, no. 1 and 2 (1998).

Corrin, J., "Keeping It Civil: The Application of French and English Laws in Vanuatu”, conference paper, Australasian Law Teachers Conference, Canberra (2013) unpublished.

Coulson, E., "The Impact of the Colonial Period on the Definition of Land Rights", in V. Turner (ed.), Colonialism in Africa (Cambridge: Cambridge University Press, 1971).

Dupret, B., Legal Pluralism, Plurality of Laws, and Legal Practices: Theories, Critiques, and Praxiological Re-Specification, 1 European Journal of Legal Studies, no.1 (2007).

Elias, T., "The Problem of Reducing Customary Laws to Writing", in A. Dundes Renteln and A. Dundes (eds.), Folk Law (Wisconsin: Wisconsin Press, 1995).

Evans, D., M. Goddard and D. Paterson, "The Hybrid Courts of Melanesia” Justice for the Poor, Justice and Development Working Paper Series No 13 (Washington: The World Bank, 2010).

Farran, S., "Customs, Laws and Traditions: Bright Lines or Grey Areas?" in Alexis Albarian and Olivier Morétau (eds.), Le droit comparé et ... Comparative Law and ..., Actes de la conférence annuelle de Juris Diversitas (Presses Universitaires d'Aix-Marseille, 2016). 
Farran, S., "A Microcosm of Comparative law: the Overlay of Customary French and English Family Law in Present Day Vanuatu" (2004) Oxford U Comparative L Forum 4 at oucif. iuscomp.org.

Farran, S., Land Leases: Research Ministerial Leases in Efate, Vanuatu, 6 Journal of South Pacific Law, no. 2 (2002), available at: <http://www.paclii.org/journals/fJSPL/vol06/6. shtml>, accessed 19 October 2016.

Farran, S., Report on Land Leases and the Use and Management of Land in the Island of Efate, Vanuatu (Vanuatu: Research Report for the Minister of Lands, 2002).

Farran, S., "Selling the Land: Should it Stop. A Case-study from the South Pacific", in M. Dixon (ed.), Modern Studies in Property Law (Vol 5, Oxford: Hart Publications, 2009).

Griffiths, J., What is Legal Pluralism? 24 Journal of Legal Pluralism (1986).

Gupta, A. (ed.), Human Rights of Indigenous Peoples (Delhi: Isha Books, 2005).

Joshua, J., “Mama Graon Program a Package of Funds: Nari”, Vanuatu Daily Post, 28 June 2012.

'Leases in Vanuatu' Key data from the World Bank Jastis Blong Evriwan Vanuatu National Leasing Profile", available at: <http://siteresources.worldbank.org/INTJUSFORPOOR/ Resources/Vanuatu_Leasing_Data_Summary.pdf>, accessed 20 April 2016.

Lunnay, C., J. Fingleton, M. Mangawai, E. Nalyal and J. Simo, Review of National Land Legislation, Policy and Land Administration (Port Vila: Vanuatu Government, 2007).

'Making Land Work', AusAID Pacific Land Program, 'Volume Two - Case Studies of Customary Land and Development in the Pacific', Australian Government Department of Foreign Affairs and Trade 2008 Canberra.

'Making Land Work', AusAID Pacific Land Program, 'Volume One - Reconciling Customary Land and Development in the Pacific'.

Manlaewia v Maripopongi [2015] VUSC 119.

McDonnell, S., "Better Protection for Custom Owners: Key Changes in Vanuatu's New Land Legislation”, Outrigger: Blog of the Pacific Institute, 4 March 2014, available at: <http://pacificinstitute.anu.edu.au/outrigger/2014/03/04/better-protection-for-customowners-key-changes-in-vanuatus-new-land-legislation/>, accessed 20 April 2016.

McDonnell, S., "Vanuatu Embraces Landmark Reforms”, EASTASIAFORUM, available at: http://www.eastasiaforum.org/2015/03/14/vanuatu-embraces-landmark-reforms/, accessed 20 April 2016.

McDonnell, S., New Territory, Pasifika, ANU, available at: <http://pasifika.anu.edu.au/ news-events/all-stories/new-territory>, accessed 29 June 2015.

Morse, B. and G. Woodman (eds.), Indigenous Law and the State (Dordrecht: Foris Publications, 1988).

Noel v Toto (Unreported. Supreme Court, Santo, Vanuatu, Kent J, 19 April 1995) available via www.paclii.org at [1995] VUSC 3.

Open letter addressed to the Prime Minister "National Sovereignty under Threat", Jeff Joel Patunvanu, The Independent, 7 July 2012.

Paterson, D., Chronicle of the Months of Political and Constitutional Crisis in Vanuatu 2014-2015, 2 Journal of South Pacific Law (2015), available at: <https://www.usp.ac.fj/ fileadmin/random_images/home_middle_banners/emalus/JSPL/2015/Issue_2/ CHRONICLE_OF_THE_MONTHS_OF_POLITICAL_AND_CONSTITUTIONAL_CRISIS_IN_VANUAT1_rev_.docx>, accessed 26 March 2016.

Priorities for Implementation by Vanuatu Government March-December 2016, available at: <https://vanuatudaily.files.wordpress.com/2012/02/salwai-govt-100-day-plan.pdf〉, accessed 26 March 2016. 
Physical Planning Act (Vanuatu) 1987.

Radio New Zealand International 16 February 2015, available at: <http://www.radionz.co.nz/ international/programmes/datelinepacific/audio/20167398/vanuatu-customary-landownership-process-begins>, accessed 20 April 2016.

Said, E., Orientalism (New York: Pantheon, 1978).

Sezgin, Y., Legal Unification and Nation Building in the Post-Colonial World: A Comparison of Israel and India, 8 The Journal of Comparative Asian Development (2009).

Simo, J. and H. Van Trease "The Vanuatu Customary Land Tribunal system", J4P World Bank, available at: <http://siteresources.worldbank.org/INTJUSFORPOOR/Resources/ VanuautcustomaryLandTribunalSystem.pdf>, accessed 1 July 2016.

Simo, J., Report of the National Review of the Customary Land Tribunal Program in Vanuatu (Port Vila: Vanuatu National Cultural Council, 2005).

The United Nations Declaration on the Rights of Indigenous People (A/61/L.67 and Add.1)

The United Nations Declaration on the Right to Development (A/RES/41/128).

The Istanbul Declaration and Programme of Action for LDCs for the decade 2011-2020.

Uritalo v Chilia [2016] VUSC 9.

Vandenborgaerde, A., The Right to Development in International Human Rights Law: A Call for Its Dissolution, 31 Netherlands Quarterly of Human Rights, no. 2 (2013).

Van Niekerk, G., “Legal Pluralism”, in Jan Christoffel Bekker, Christa Rautenbach and Nazeem Muhammed Ismail Goolam (eds.), Introduction to Legal Pluralism in South Africa (Durban: Lexis Nexis South Africa, 2002).

Van Trease, H. and J. Simo, "Report on the Activities of the Vanuatu Customary Land Tribunal and the 2001 Act”, NZAID, February 2011.

Von Benda Beckman, F., Citizens, Strangers and Indigenous Peoples: Conceptual Politics and Legal Pluralism, 9 Law and Anthropology (1997).

Woodman, G., "The Idea of Legal Pluralism”, in Baudouin Dupret, Maurits Berger and L. Al-Zwaini (eds.), Legal Pluralism in the Arab World (Leiden: Brill, 1999). 